\title{
The cork oak in the Mountains of Palermo (Italy): ecological insights from the south-eastern edge of its distribution range
}

\author{
Emilio Badalamenti ${ }^{(1)}$, \\ Riccardo Scalenghe ${ }^{(1)}$, \\ Tommaso La Mantia ${ }^{(1)}$, \\ Rafael da Silveira Bueno ${ }^{(1)}$, \\ Giovanna Sala ${ }^{(1)}$, \\ Giuseppe Maria Pizzurro ${ }^{(1)}$, \\ Andrea Giaimo ${ }^{(1)}$, \\ Salvatore Pasta ${ }^{(2)}$
}

\begin{abstract}
The uneven presence of the cork oak (Quercus suber L.) within its distribution range is not only determined by its climatic requirements but also by specific edaphic needs. Although most of the natural populations thrive in acidic soils deriving from metamorphic or volcanic rock outcrops, some cork oak populations are found growing in soils deriving from calcareous bedrock, which are considered less suitable. We carried out a multidisciplinary investigation at the south eastern edge of the $Q$. suber distribution range (Mountains of Palermo, NW Sicily), including soil, floristic, and vegetation surveys, aimed at: (i) assessing the native or introduced origin of some peculiar cork oak populations; (ii) describing the associated plant communities and soils; (iii) identifying the ecological factors which could explain the local adaptation to soils deriving from calcareous bedrock; (iv) discussing the ecological role played by this species in the study area and within its distribution range. The collected information suggest that the detected cork oak stands are native to these areas. We hypothesized that the co-occurrence of high fire frequency, high soil calcium content and erosion, which caused the intermixing of different parent materials, might favor its competitive interactions with other Mediterranean tree species, thus accounting for the local presence of $Q$. suber. The study of cork oak populations thriving in peculiar substrates at the driest end of the range could be of great importance for the future conservation of this species, which is expected to face growing threats in the coming decades.
\end{abstract}

Keywords: Mediterranean Evergreen Forest, Soil Chemistry, Vegetation Science, Wildfire, Landscape, Tree Species, Quercus suber
The cork oak shows a discontinuous geographical distribution, much more restricted and fragmented than might be expected based on its climatic requirements. However, compared to other evergreen oaks, Q. suber is characterized by a more restricted ecological niche, as particularly demanding in terms of soil humidity (Petroselli et al. 2013). The species grows in warm-humid Mediterranean areas with oceanic features, receiving at least $450 \mathrm{~mm}$ of mean annual rainfall, from sea level up to $2000 \mathrm{~m}$ a.s.l., although most cork oak stands are found below $800 \mathrm{~m}$ a.s.l. (Houston Durrant et al. 2016).
(1) Department of Agricultural, Food and Forest Sciences, University of Palermo. v.le delle Scienze Ed. 4, I-90128 Palermo (Italy); (2) Institute of BioSciences and BioResources (IBBR), Italian National Council of Research (CNR), Unit of Palermo, C.so Calatafimi 434, I-90129, Palermo (Italy)

@ Tommaso La Mantia (tommaso.lamantia@unipa.it)

Received: Jan 27, 2020 - Accepted: Jun 06, 2020

Citation: Badalamenti E, Scalenghe R, La Mantia T, Bueno RS, Sala G, Pizzurro GM, Giaimo A, Pasta S (2020). The cork oak in the Mountains of Palermo (Italy): ecological insights from the south-eastern edge of its distribution range. iForest 13: 336-344. - doi: 10.3832/ifor3360-013 [online 2020-08-07]

Communicated by: Francisco Lloret Maya
Soil physical-chemical characteristics are regarded as being among the ecological factors most correlated to the occurrence of the cork oak in its natural range (Petroselli et al. 2013). Q. suber generally prefers sandy soils derived from siliceous rocks with acid reaction, while usually avoids soils from base-rich, calcareous bedrocks such as dolomitic limestones, calcareous sandstones, and marls (Serrasolses et al. 2009). Indeed, the importance of various substrate-related variables, particularly lithology and soil type (Costa et al. 2008), for the distribution of cork oak has been repeatedly acknowledged. The preference for well drained soils with coarse textures is known (Laakili et al. 2016). Conversely, reduced organic matter availability or soil acidification have negative effects on cork oak regeneration in the longer term (Dias et al. 2016).

There is increasing evidence of a declining trend in cork oak populations, especially at the edge of the species' natural distribution range (Vessella et al. 2017, Matías et al. 2019). Many factors have been invoked to explain the ongoing process, which is bound to increase in the forthcoming decades based on current climate change scenarios (Matías et al. 2019), and due to other growing threats, such as overgrazing, soil pathogens and land-use changes (Dettori et al. 2018). In the Mediterranean 
region, climatic forecasting seem to indicate a rise in temperatures and a reduction in precipitation, which will probably decrease the potentially suitable areas for cork oak, especially in the southern edge and at lower altitudes; accordingly, northward and upward shifts could occur (Vessella et al. 2017). Indeed, the expected reduction in soil water availability could favor other co-occurring and more drought-tolerant woody species, such as holm oak (Quercus ilex L. - Petroselli et al. 2013). Aridity has been found to play a key role in Q. suber regeneration ability, markedly hindering seedling recruitment chance and originating over time an aged demographic structure (Matías et al. 2019).

In Italy, the most extensive cork oak forests occur in Sardinia (82.7\% of total national area), followed by Sicily, Tuscany and Calabria, while more discontinuous and smaller nuclei are found in Campania, Lazio and Apulia (INFC 2007). In Sicily, Quercus suber is a native species which covers approx. 19,000 ha, from sea level up to 1000 $\mathrm{m}$ a.s.l. It accounts for approx. $7 \%$ of total regional forest cover (Camerano et al. 2011), in some cases characterizing old growth stands (Badalamenti et al. 2018). Only $41.3 \%$ of the Sicilian cork oak stands are currently managed for production and the progressive abandonment of cork cultivation is considered to be a threat to the conservation of these ecosystems on a regional scale. Furthermore, since these populations grow at the driest end of the spe- cies' range, they are particularly prone to the effects of climate change, and could suffer from a marked reduction and local extinction in the next future (Vessella et al. 2017). For this reason, they are of particular interest for the future dynamics of cork oak in the whole Mediterranean Basin. In specific reference to the cork oak, according to Aronson et al. (2009): “Knowledge of species requirements and constraints can be used to promote conservation and restoration efforts or to expand its current distribution limits in view of the current climate and land use changes".

In this study, we aimed to gain ecological insights from the cork oak stands occurring in NW Sicily in soils deriving from calcareous bedrock, which are generally considered to be less suitable for the species. In particular, we characterized soil and plant communities associated to cork oak stands, occurring at the southeastern edge of its natural distribution range. The main objectives of the study were to: (i) identify and quantify the area covered by cork oak populations in the Mountains of Palermo (NW Sicily); (ii) investigate the effective origin of these populations (whether natural or artificial) based on historical and floristic information; (iii) identify the ecological factors responsible for the presence of the species in soils that developed on calcareous substrates; (iv) propose a synthetic interpretation of the ecological role played by the cork oak within local potential vegetation.

\section{Materials and methods}

\section{Identification and characterization of}

the study areas

In order to detect any cork oak population, either as forest stand, small nucleus or isolated individual, the main botanical literature concerning the Mountains of $\mathrm{Pa}$ lermo (the mounts surrounding Palermo city) was consulted (Marcenò \& Trapani 1978). The historical information gathered was used to identify potential areas covered by Q. suber. After being validated through dedicated field surveys, the detected areas were characterized by adopting the hierarchical classification developed by Blasi et al. (2000); this method entailed overlapping the pedological map (scale 1:250.000 - Fierotti 1988) with the geological map (scale 1:250.000 - Lentini \& Carbone 2014), the bioclimatic map (scale 1:250.000 - Bazan et al. 2015), and the map of Sicilian potential vegetation (scale 1:250.000 - Anonymous 1996; see Tab. S1 in Supplementary material). Three macro-areas, geographically distinct from one other and fairly homogeneous in terms of substrate (geology and soil types), were identified (Tab. 1): (i) macro-area A: "Pianetto" (municipalities of Altofonte and Santa Cristina Gela); (ii) macro-area B: "Cozzo Secco" (municipality of Borgetto); (iii) macro-area C: "Colline della media valle del fiume Oreto e del Monrealese" (municipalities of Altofonte and Monreale).

The occurrence of the cork oak had al-

Tab. 1 - Main characteristics of the study areas. Sources: (1): Fierotti (1988); (2): Lentini \& Carbone (2014); (3): Bazan et al. (2015).

\begin{tabular}{|c|c|c|c|}
\hline \multirow{2}{*}{ Characteristics } & \multicolumn{3}{|c|}{ Macro-area } \\
\hline & A & B & C \\
\hline Locality & $\begin{array}{l}\text { Pianetto (Cozzo Giammeri and } \\
\text { Costa Zolia) }\end{array}$ & Cozzo Secco & $\begin{array}{l}\text { Colline della media Valle del fiume } \\
\text { Oreto e del Monrealese }\end{array}$ \\
\hline Stand description & $\begin{array}{l}\text { Small, isolated and discontinuous, } \\
\text { grazed, pure stand or mixed with } \\
\text { holm and downy oak }\end{array}$ & $\begin{array}{l}\text { Scattered and discontinuous } \\
\text { stands, grazed, mixed with } \\
\text { evergreen thermophilous } \\
\text { sclerophyllous species or with } \\
\text { downy oak }\end{array}$ & $\begin{array}{l}\text { Isolated plants and small nuclei, } \\
\text { discontinuous, pure stands or } \\
\text { mixed with evergreen } \\
\text { thermophilous species }\end{array}$ \\
\hline Municipality & Altofonte, Santa Cristina Gela & Borgetto & $\begin{array}{l}\text { Monreale, Altofonte, Marineo, } \\
\text { Montelepre, Giardinello }\end{array}$ \\
\hline $\begin{array}{l}\text { Regional Technical Map } \\
1: 10.000 \text { (Section no.) }\end{array}$ & 595130 and 608010 & 594140 & 594120 and 594160 \\
\hline $\begin{array}{l}\text { Maximum range of } \\
\text { UTM Coordinates }\end{array}$ & $\begin{array}{l}\text { E 2373518-2374629 } \\
\text { N } 4206720-4208280\end{array}$ & $\begin{array}{l}\text { E 2356966-2357797 } \\
\text { N } 4209665-4210804\end{array}$ & $\begin{array}{l}\text { E } 2370475-2371368 \\
\text { N } 4213457-4217808\end{array}$ \\
\hline Area (ha) & 251 & 50 & 240 \\
\hline Mean altitude (m a.s.l.) & 720 & 560 & 480 \\
\hline Altitudinal range ( $\mathrm{m}$ a.s.l.) & $597-835$ & $432-659$ & $240-680$ \\
\hline Slope (\%) & 20 & 20 & 30 \\
\hline Main aspect & NO-SE & SW & None \\
\hline Soil type ${ }^{1}$ & $\begin{array}{l}\text { Leptosols, Regosols, Phaeozem } \\
\text { (Association 7) }\end{array}$ & Leptosols (Association 6) & $\begin{array}{l}\text { Leptosols, Regosols, Phaeozem, } \\
\text { Cambisols (Associations } 21 \text { and 29) }\end{array}$ \\
\hline Lithotype $^{2}$ & $\begin{array}{l}\text { Calcilutites and marls, } \\
\text { calcarenites grading up to } \\
\text { doloarenites and dolorudites } \\
\text { (Geology 42) }\end{array}$ & $\begin{array}{l}\text { Silicoclastic deposits, yellowish } \\
\text { graded quartzarenites and brown } \\
\text { clays (Geology } 8 \text { and 30) }\end{array}$ & $\begin{array}{l}\text { Radiolarites and Spongolites with } \\
\text { redeposited calcarenites and } \\
\text { calcirudites, and red marls } \\
\text { (Geology } 41 \text { ) }\end{array}$ \\
\hline Bioclimate $^{3}$ & $\begin{array}{l}\text { thermo-Mediterranean upper sub- } \\
\text { humid }\end{array}$ & $\begin{array}{l}\text { thermo-Mediterranean lower sub- } \\
\text { humid }\end{array}$ & $\begin{array}{l}\text { thermo-Mediterranean upper sub- } \\
\text { humid }\end{array}$ \\
\hline
\end{tabular}


ready been reported in macro-area $A$ (at Dingoli site) by Marcenò \& Trapani (1978), while cork oak forests have been present in macro-area B at least since XIII century, when the territory was owned by the Abbey of "Santa Maria di Altofonte" (Bresc 1983). Conversely, no previous historical data was available on the occurrence of $Q$. suber in macro-area $C$.

Subsequently, we searched for local data on wildfires, as they are an important factor explaining the natural distribution of the cork oak in the Mediterranean, as well as in our study areas. Information collected by the Special Office of the Firefighting Forest Fire Service (USSAB 2005), for the period preceding our field surveys, and by the Command of the Forest Service of Sicily for more recent data (2007-2019 https://sifweb.regione.sicilia.it/arcgis/rest/s ervices/Censimento_Incendi/MapServer), was considered. The oldest data are sorted by municipality and they provide information on the occurrence of wildfires in Sicily in the years 1986-2002 (USSAB 2005). In detail, in the framework of the Regional plan for the protection of vegetation from fires, a regional map of fire risk was developed, not only considering the factors which enhance the likelihood of wildfire (e.g., vegetation types or climate traits), but also taking into account the frequency of wildfires occurring in a given area, as well as the average affected area and the average affected wooded area, thus including a quantitative assessment. In particular, this map was elaborated through the overlapping of different base maps, including a statistical risk map, a vegetation risk map, a climate risk map, and a morphological risk map.

For a climatic and bioclimatic characterization of the study areas, the thermopluviometric stations of Partinico (189 $\mathrm{m}$ a.s.l.) and Monreale (310 m a.s.l. - Duro et al. 1993, SIAS, http://www.sias.regione.sicilia. it/) were considered the most suitable (Tab. 2). Taking into account their location, the Partinico station was used to characterize macro-area $B$, while the Monreale station was used for macroareas $A$ and $C$. Annual precipitation ranged from $706 \mathrm{~mm}$ (Partinico) to $991 \mathrm{~mm}$ (Monreale), while mean temperature ranged from $16.2{ }^{\circ} \mathrm{C}$ (Monreale) to $17.8^{\circ} \mathrm{C}$ (Partinico). Raw climatic data were used to identify the duration of the drought-stress period, which generally spans from the third ten-day period of April to the third ten-day period of September in both stations. According to Rivas-Martínez (1996), as well as local classification schemes (Bazan et al. 2015), the bioclimate for macro-area $B$ is thermoMediterranean lower sub-humid, while for macro-areas A and C, the bioclimate is thermo-Mediterranean upper sub-humid.

\section{The cork oak distribution map}

A distribution map of the cork oak, either found as forest stand, small nucleus and/or isolated individual, was made in a GIS environment. Field data were registered by means of a Trimble ${ }^{\oplus}$ GPS (Trimble Inc., Sunnyvale, CA, USA). Data referring to the UTM plane coordinate system, timed to share information, latitude and longitude, were exported as shapefiles to be treated with QGIS ${ }^{\circledast}$ ver. 3.10 (QGIS Development Team) and were overlapped with sections no. 594140, 595130, 594120, 594160 and 608010 of the Regional Technical Map (scale 1:10.000). The shape relative to punctual distribution files of cork oak was then overlapped with the soil, geological and bioclimatic maps.

\section{Soil surveys}

The choice of the most suitable areas for the pedological surveys was based on two steps: after superimposing the cork oak distribution map with the geological map, direct field observations of the soil features and plant species assemblages (acidophilous vs. basiphilous) were carried out. The benchmark pedons (=soil profiles) representative of the main soil types (Tab. 1) were described in the field after direct soil excavation and according to the genetic horizons defined by Schoeneberger et al. (2002). Overall, 5 pedons, sampled in bulk and undisturbed soil horizons, were described: four pedons belonging to macroarea $\mathrm{A}$, and one pedon belonging to macroarea $\mathrm{B}$. No pedon was considered in macroarea $C$ because it was not possible to access the privately owned areas. Pedon 1 (Code Ag1) and pedon 2 (Code Ag2) were located at Cozzo Giammeri ( $38^{\circ} 00^{\prime} 23.80^{\prime \prime}$ $\mathrm{N}, 13^{\circ} 20^{\prime} 34.41^{\prime \prime} \mathrm{E}$ ), pedon 3 (Code Az3) and pedon 4 (Code Az4) were located at Costa Zolia ( $\left.37^{\circ} 59^{\prime} 50.75^{\prime \prime} \mathrm{N}, 13^{\circ} 20^{\prime} 49.64^{\prime \prime} \mathrm{E}\right)$, and pedon 5 (Code B) was located at Cozzo $\operatorname{Secco}\left(38^{\circ} 01^{\prime} 31.15^{\prime \prime} \mathrm{N}, 13^{\circ} 09^{\prime} 07.21^{\prime \prime} \mathrm{E}\right)$. For each pedon, three soil samples were collected at several soil depths. Bulk soil samples were air dried, crushed and 2-mm sieved. Particle size distribution was determined by sieving and sedimentation (ISO 11277:2009): total carbonates volumetrically, pH potentiometrically (ISO 10390:2005) and soluble ions by ion chromatography of saturated-paste water extracts (Dionex DX$120^{\circledR}$, Sunnyvale, CA, USA). Soil classification followed the IUSS Working Group (2015).

Tab. 2 - Precipitation and temperature data in the considered thermo-pluviometric stations.

\begin{tabular}{llcc}
\hline \multirow{2}{*}{ Variable } & Parameter & \multicolumn{2}{c}{ Meteo Stations } \\
\cline { 3 - 4 } & & Partinico & Monreale \\
\hline $\begin{array}{llcc}\text { Precipitation } \\
(\mathrm{mm})\end{array}$ & Mean annual & 706 & 991 \\
\cline { 2 - 4 } & Monthly maximum & 97 & 129 \\
\cline { 2 - 4 } $\begin{array}{l}\text { Temperature } \\
\left({ }^{\circ} \mathrm{C}\right)\end{array}$ & Menthly minimum & 4.3 & 4.7 \\
\cline { 2 - 4 } & Mean annual & 17.8 & 16.2 \\
\cline { 2 - 4 } & Average of the maximum & 22.6 & 21.3 \\
\cline { 2 - 4 } & Maximum of the minimum & 12.7 & 11.4 \\
\cline { 2 - 4 } & Minimum average of the hottest month & 31.8 & 31.1 \\
\hline
\end{tabular}

Floristic and vegetation surveys

Floristic and phytosociological surveys were carried out during spring 2004. Analysis of cover-value ranges available from vegetation surveys on evergreen forests in Sicily (see Brullo et al. 2009 and literature therein) suggested the use of $20 \%$ as a valuable threshold for the cover of $Q$. suber. Full vegetation surveys, within $100 \mathrm{~m}^{2}$-wide plots, were carried out only within the subpopulations where cork oak cover exceeded $20 \%$. Four plots were established in macro-area $A$, and seven plots were established in each of the macro-areas B and C, which included the most interesting cork oak stands. For each plant species, the cover/dominance scale proposed by BraunBlanquet (1932) was considered, with modifications subsequently proposed by Pignatti \& Mengarda (1962). The Shannon diversity index (H' - Shannon 1948) and Evenness index (Pielou J) were calculated after converting Braun-Blanquet values according to Tüxen \& Ellenberg (1937). Classification of the vascular plants followed Pignatti et al. (2017) and hierarchical classification of the plant communities followed Guarino et al. (2017). Each plant species surveyed was included in one of the following cion ilicis, including pure evergreen or mixed ever- and summer-green oak forest species linked to neutrocline-acid soils (EQi); (ii) Quercion ilicis, including pure evergreen or mixed ever- and summer-green oak forest species (Qi); Oleo-Ceratonion siliquae, including maquis species (OCs); (iii) PrunoRubion ulmifolii, including mantle species (PRu); (iv) Cisto-Ericion multiflorae, including garrigue species (CEm); (v) Hyparrhenion hirtae, including xerophilous grassland species (Hh); (vi) Other species belonging to other syntaxa.

Where only a few scattered individuals of cork oak occurred in open and discontinuous plant communities (cork oak cover $<20 \%$ ), we considered only the presence/ absence of diagnostic vascular plants typical of forest and pre-forest communities (maquis, mantle, garrigue and grassland), as well as of species characteristic of rocky and scree habitats. In these areas, we aimed to highlight whether a high number phytosociological alliances: (i) Erico-Quer- 
of species characteristic of Erico-Quercion ilicis could support the past occurrence of cork oak forests. The authors of all scientific epithets concerning plants mentioned in the text are provided in Tab. S2 (Supplementary material).

\section{Statistical analysis}

To test the effects of the environmental variables, namely altitude, main aspect (north or south) and lithology (calcareous or flysch) on richness, diversity (Shannon $\mathrm{H}^{\prime}$ ) and evenness (Pielou J), we used a general linear model (GLM). Before running the model, we first checked that the three dependent variables followed a normal distribution (Shapiro-Wilk test: $p=0.55,0.23$ and 0.85 , respectively). Spatial autocorrelation across the sampling plots using Moran's I index, calculated from three different weight matrices (i.e., distance to the nearest neighbor) was also checked (Dormann et al. 2007). We set the distance range at $2300 \mathrm{~m}$, which was the minimum distance to allow all plots to have at least one neighbor. We then set the range at $4300 \mathrm{~m}$ to connect all plots inside the same macro-area, and finally we used a "queen" matrix, searching for the first closest neighbor without a maximum distance threshold, thus connecting at least one neighbor from all macro areas. To test for differences in richness, diversity, and evenness between the three macro-areas, we used one-way ANOVA, after verifying the homogeneity of variances in the residuals

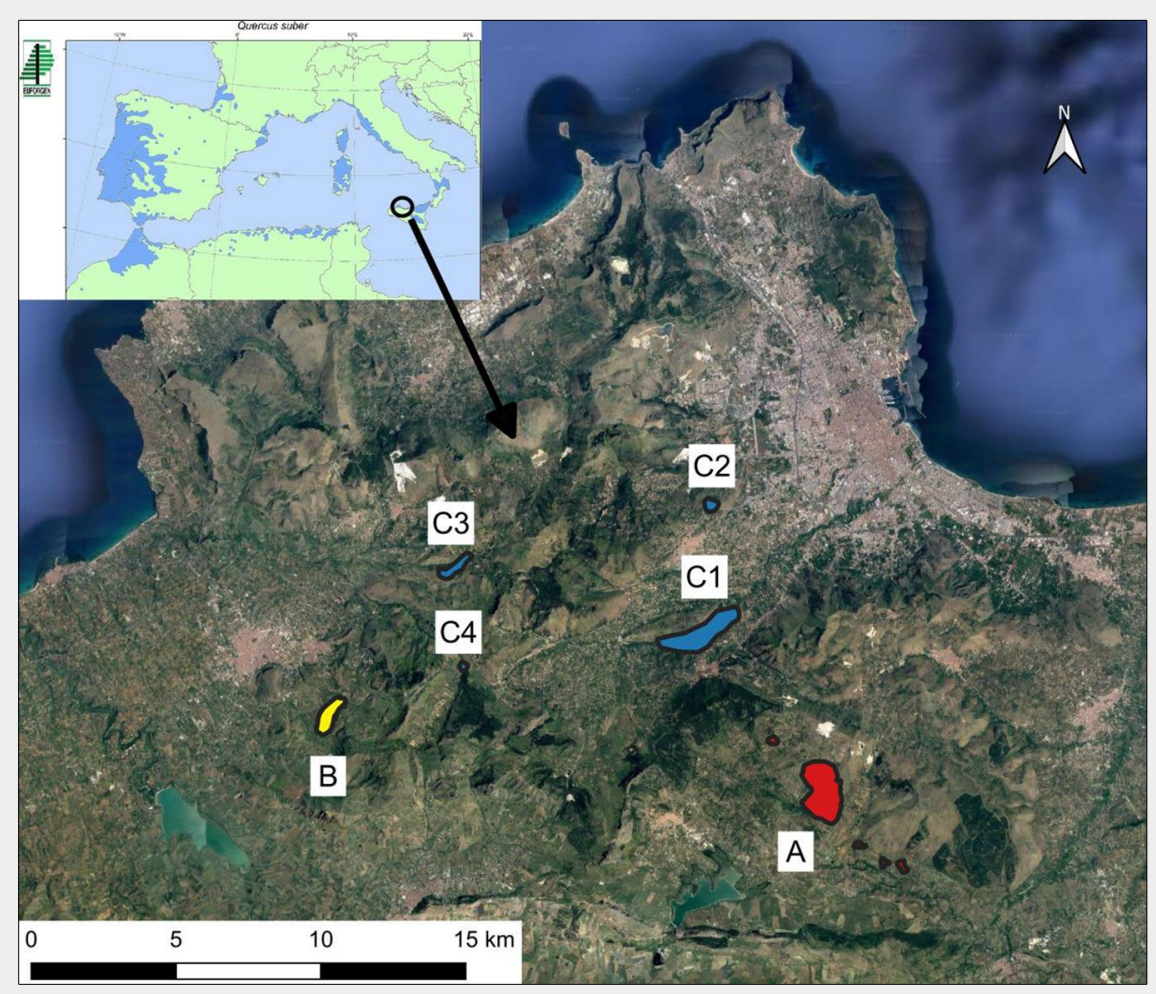

Fig. 1 - The cork oak distribution map in the Mountains of Palermo. The different letters indicate the three macro-areas (A, B and C). Up on the left, the natural distribution range of Quercus suber is reported (EUFORGEN 2019). 2006).

\section{Results}

Distribution and characterization of the study areas rotti 1988, Lentini \& Carbone 2014). of the model (Levene's test: $p=0.69,0.50$ and 0.12 , respectively). All statistical analysis was performed in $\mathrm{R}$ v. 3.6.1 ( $\mathrm{R}$ Core Team 2019) and spatial autocorrelation was assessed with GEODA 1.8.16 (Anselin et al.

The distribution map of the areas where cork oak occurs in the Mountains of $\mathrm{Pa}$ lermo is shown in Fig. 1. Macroarea $A$ is mainly characterized by calcilutites, marls, and calcarenites grading up to doloarenites and dolorudites, and Leptosols, Regosols, and Phaeozem (Fierotti 1988, Lentini \& Carbone 2014). Macroarea B is mainly characterized by Silicoclastic deposits, Numidian Flysch, and mainly Leptosols (Fierotti 1988, Lentini \& Carbone 2014). Macroarea C is mainly characterized by Radiolarites and Spongolites with redeposited calcarenites and calcirudites, red marls, and Leptosols, Regosols, Phaeozem, and Cambisols (Fie-

Macro-area $A$ has a surface of about 251 ha and is localized in the south-east sector of the map. Macro-area B is around 50 ha wide and is localized in the south-west sector of the map. Macro-area C is approx. 240 ha wide, encompassing much more fragmented and isolated stands, localized in the northern sectors of the map. Overall, the areas under investigation, covered by These soils evolved from lithological substrates made of siliceous shales, radiolarites and marls, with interbedded lenticular resedimented breccias. Graded and laminated calcareous sandstone with elements from Middle-Upper Triassic Cretaceous platforms occurred in pedon 3 and pedon 4. Cozzo Giammeri profiles (Ag1 and Ag2) evolved on slopes with a gradient of 15 and $25 \%$, respectively, while Costa Zolia profiles (Az3 and Az4) evolved on slopes with a gradient of $10 \%$. The pedon differed in terms of stoniness and rockiness. The main land use was overgrown pastureland. In macro-area $B$, pedon 5 belonged to Leptosols, which evolved on lithological substrates made of graded doloarenites and dolorudites, and re-sedimented dolomite breccias with megabreccias from Triassic carbonate platforms. This profile was open on one side in a slope with a gradient of $35 \%$, stoniness of $25 \%$, rockiness of $20 \%$ and moderately rapid drainage. A morphological description of all pedons is given in Tab. S3 (Supplementary material). Average soil $\mathrm{pH}$ ranged between 6 and 7 in all study sites. Variability of soil $\mathrm{pH}$ increased almost linearly with a soil depth of up to $80 \mathrm{~cm}$ (ranging from 5.0 to 7.8); conversely, it decreased progressively at higher soil depths (Fig. 2). Overall, the large variability in soil $\mathrm{pH}$ (from 4.6 to 7.8 ) showed good plasticity of cork oak to this edaphic factor. $\mathrm{Na} / \mathrm{Ca}$ 
molar ratios were constantly higher than 1 , $\mathrm{Mg} / \mathrm{Ca}$ ratio exceeded 0.6 , while $\mathrm{Na} / \mathrm{K}$ ratio exceeded 20 (Fig. 3).

\section{Floristic and vegetation surveys}

Despite evenness being autocorrelated in the two close range matrices, source variable richness as well as diversity were not autocorrelated in all matrices (Moran's I $p$ $>0.05$ in all cases - Tab. S4), suggesting high local scale variability. GLM indicated that richness, diversity and evenness are not predicted by altitude, aspect and lithology ( $p>0.05$ in all cases - Tab. 3), and they did not differ between the macro areas (richness: $\mathrm{F}=0.24, \mathrm{P}=0.78$; diversity: $\mathrm{F}=$ $0.74, p=0.49$; evenness: $F=1.01, p=0.38$ ). However, significant differences $(F=7.92$, $p<0.01)$ were found in the richness of species belonging to the alliance dominated by $Q$. suber (EQi), which was significantly higher in macro-area $\mathrm{B}$ than in $\mathrm{C}$, although not differing from A (after Tukey HSD test). High degradation and fragmentation of forest habitats in the surveyed areas can be inferred from the number of plant taxa not framed within any alliance (see "Other Species" in Fig. 4 and Tab. S2 in Supplementary material), as well as from those belonging to the alliance $\mathrm{Hh}$. In all macro-areas, plant taxa belonging to "other species" represented the dominant component of plant communities, ranging from $38.6 \%$ in macro-area $B, 39.8 \%$ in C and up to $42.5 \%$ in A (Fig. 4).

Macro-area $A$ is characterised by a complex and heterogeneous landscape, due to extreme variability in local topography (aspect and slope), continuous shifts from carbonate (compact calcarenites and calcilutites) to acid (quartz sandstones) outcropping rocks, as well as to major disturbance factors (mostly cattle grazing and fires). Here, cork oak stands, pure or mixed with a number of evergreen or deciduous trees, are intermingled with more open thermophilous maquis on S-facing ridges and summits. Quercus suber does not seem to play a dominant role in the absence of human disturbance. These forest communities show excellent potential for recovery and future development, although the possibility of establishing the potential vegetation (Quercetalia pubescenti-petraeae) with downy oak as the dominant tree species (Anonymous 1996) is currently low. In fact, the current floristic composition of local communities is rich in plants linked to rocky habitats and overgrazed pasturelands, showing clear signs of soil degradation and thinning processes. Some cooler and shady microhabitats are suitable for Cephalanthera longifolia, Quercus congesta and Iris foetidissima, which are rare species on the Mountains of Palermo (Pasta \& Troìa 1994).

In macro-area B, the cork oak stand is uneven-aged, almost pure, mostly sparse and discontinuous, and rather plant species poor. High wildfire frequency is witnessed by the extremely high number of species

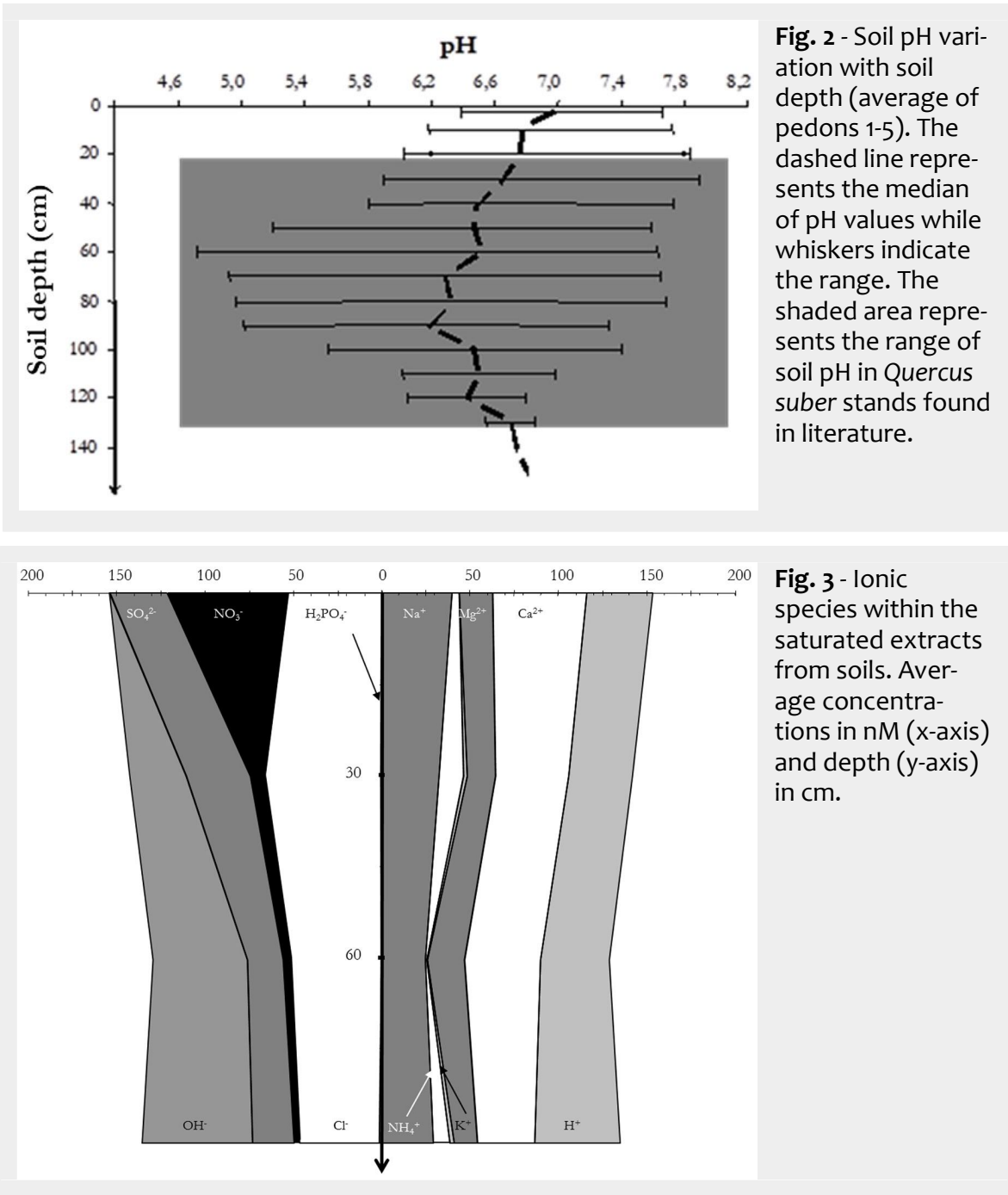

tied to open patches of perennial grassland dominated by Ampelodesmos mauritanicus or of acidophilous garrigue dominated by Cistus spp. and Lavandula stoechas, while the current intensity of cattle grazing is underlined by high numbers of mantle and grassland species. Only near rocky outcrops, especially along ridges and on hilltops, a higher frequency of Mediterranean maquis species was recorded. In small valleys, where soils are deeper and the effect of wind is slightly mitigated, some scattered individuals of downy oak (Quercus pubescens Willd. s.l.) co-occur with cork oak, while the shrubby understory is dominated by Cytisus villosus. This plant community may be framed within the Erico-Quer-

cion ilicis, due to the high number of species referred to this alliance, in addition to acidophilous species such as Lavandula stoechas, Limodorum abortivum, Pteridium aquilinum, and Tuberaria guttata. We may hypothesize that local forest communities belonged in the past to the Erico arboreaeQuercetum virgilianae, rather widespread in the Tyrrhenian sector of Sicily (Brullo et al. 2009).

Macro-area $C$ is subdivided into four subareas geographically disjoint from each other (Fig. 1). The most interesting cork oak stands occur in the southeast sub-area, where the semi-natural landscape appears rather uniform: a series of ridges whose Sfacing slopes usually host thermophilous

Tab. 3 - Summary of the results of the GLM testing the effects of the three environmental variables on richness and diversity.

\begin{tabular}{lcccccccccc}
\hline \multirow{2}{*}{ Variable } & \multicolumn{3}{l}{ Richness } & $\left(\mathbf{R}^{2}=\mathbf{0 . 2 2}\right)$ & \multicolumn{3}{c}{ Diversity } & $\left(\mathbf{R}^{2}=\mathbf{0 . 1 3}\right)$ & \multicolumn{3}{c}{ Evenness $\left(\mathbf{R}^{2}=\mathbf{0 . 0 5}\right)$} \\
\cline { 2 - 11 } & Estimate & $\mathbf{t}$ & $\mathbf{p}$ & Estimate & $\mathbf{t}$ & $\mathbf{p}$ & Estimate & $\mathbf{t}$ & $\mathbf{p}$ \\
\hline Intercept & 35.506 & 3.1 & $<0.001$ & 2.019 & 5.72 & $<0.001$ & 0.558 & 8.26 & $<0.001$ \\
Altitude & 0.028 & 1.36 & 0.2 & 0.001 & 0.83 & 0.42 & 0 & 0.49 & 0.63 \\
Aspect & -0.027 & 0.02 & 0.98 & 0.003 & 0.03 & 0.98 & 0.002 & 0.11 & 0.91 \\
\hline Lithology & 6.64 & 1.86 & 0.08 & 0.155 & 1.41 & 0.18 & 0.018 & 0.83 & 0.42 \\
\hline
\end{tabular}




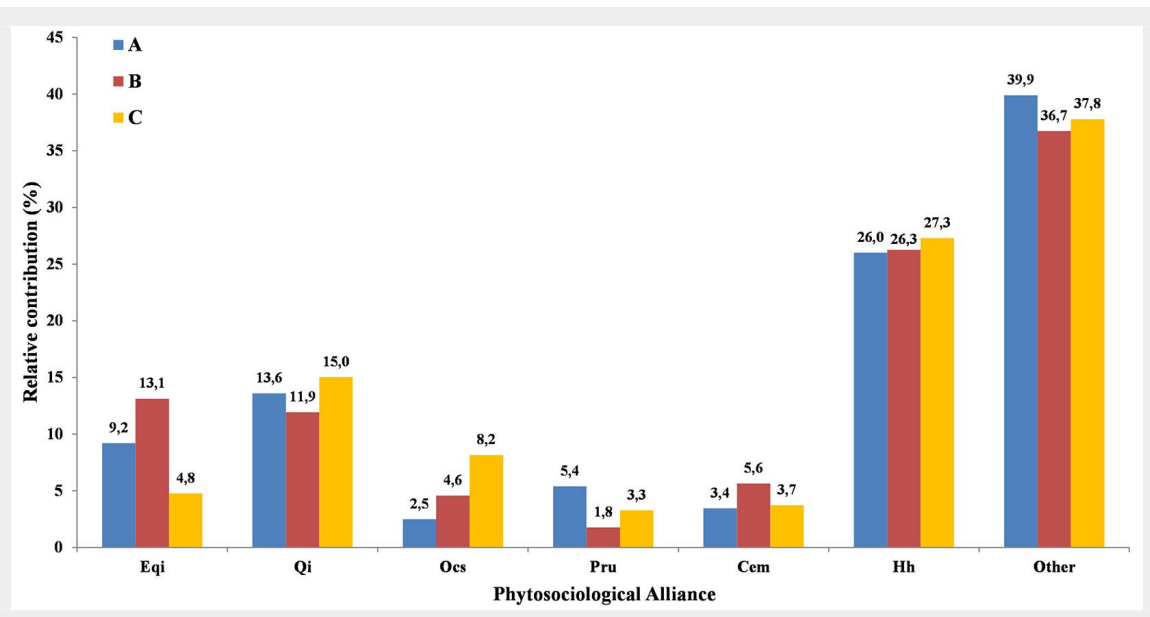

Fig. 4 - The relative contribution (in \%) of each surveyed phytosociological alliance within each macro-area (A, B and C). (EQi): Erico-Quercion ilicis; (Qi): Quercion ilicis; (OCS): Oleo-Ceratonion siliquae; (PRu): Pruno-Rubion ulmifolii; (CEm): Cisto-Ericion multiflorae; (Hh): Hyparrhenion hirtae; (Other): species belonging to other syntaxa.

taxa and assemblages, while $\mathrm{N}$-facing slopes host some remnant nuclei of Mediterranean oak forests. It is therefore quite difficult to assign local plant assemblages to a plant association. On more acidic substrates, like quartz sandstones and argillites, local forest communities probably belonged to the Erico-Quercion ilicis alliance, or alternatively to the Erico arboreae-Quercetum virgilianae plant association. Elsewhere, the high frequency of woody species typical of Oleo-Ceratonion, which represents the potential vegetation of this area (Anonymous 1996), supports the hypothesis that cork oak locally belonged to the Oleo sylvestris-Quercetum virgilianae. Most of the cork oak stands in this macroarea are very scattered and open, forming a patchwork with xeric perennial grasslands dominated by Ampelodesmos mauritanicus or with mantle communities physiognomized by Crataegus monogyna, Cytisus infestus, Osyris alba, Daphne gnidium, Spartium junceum, Pistacia terebinthus and $P$. lentiscus. Intense and widespread soil erosion processes, and frequent wildfires caused extreme soil and habitat degradation. The high degree of soil thinning may also be inferred by the high frequency of species adapted to cliffs, ledges and screes, as observed in the small stand of "Contrada Loghi Vecchi" (Monte Caputo see Tab. S5 in Supplementary material).

\section{Discussion}

Our study provides ecological insights from Quercus suber stands occurring on the Mountains of Palermo, at the southeast edge of its distribution range. The pedological characteristics obtained by direct soil excavation and pedon observation (Corona et al. 2005) allowed to infer some interesting indications on the ecological range of Q. suber in terms of soil variables. Recent research has emphasized the need for very detailed field data when studying cork oak stands (Vessella et al. 2017). The same is true for our study sites, as the calcareous nature of the substrates is different from the typical siliceous rocks with acid reaction, where most of the cork oak stands occur.

Our study sites fall within areas considered to be of particular interest for the future dynamics of cork oak, as they could face growing risk of local extinction, or a significant reduction in the population size (Vessella et al. 2017) due to many interacting detrimental factors (climate change, fire frequency, etc.) driven by man (Matías et al. 2019). Our field observations and wildfire data clearly proved that the surveyed cork oak stands are highly exposed to these risks.

The occurrence of species typical of the Erico-Quercion ilicis (EQi) may represent an effective proxy for assessing the native status of local Q. suber populations. A high frequency of base-avoiding plant species typical of the EQi was recorded in the understory of the surveyed cork oak stands. Since many of these species show high fidelity to cork oak stands throughout the whole island (Brullo et al. 2009), all the macro-areas have very good potentiality for Q. suber. As historical data (Bresc 1983, Gussone 1842, Lojacono-Pojero 1888, Parlatore 1848) testify the local occurrence of Q. suber at least since the Middle Ages, and considering that the first afforestations in Sicily started around 1920s, cork oaks should be considered locally native in these areas and the hypothesis of a past introduction in pre-existing woodlands should be discarded.

Cork oak stands growing on alkaline or neutral-alkaline soils have been already observed in western and southeastern Sicily (Minissale et al. 2006), as well as in southern Latium (central Italy), where they have been interpreted as steady "disclimax" communities favoured by century-long fire disturbance to the detriment of local "climax" forests dominated by holm and/or downy oak (Blasi et al. 1997). In our study areas, three main factors, probably acting in synergy, could account for the scattered but persistent occurrence of Q. suber: (i) local fire disturbance; (ii) the peculiar characteristics of local soils; and (iii) the effect of erosion processes on the local geological framework.

High fire frequency, as observed in all macro-areas, could have hindered evolution towards more mature forest ecosystems, favouring the more fire-resistant cork oak, once a minor component of pristine mixed oak forests (Barberis et al. 2003). Indeed, Q. suber is a fire-resistant tree species with a thick bark acting as an insulating material and protecting the inner woody structures. After fire passage, the cork oak is also able to resprout both from stem and basal buds (Pausas 1997), showing a notably high survival rate (Sirca et al. 2015). The marked effect of human disturbance on local plant communities can also be derived by the fact that none of the abiotic factors assessed (altitude, aspect and lithology) proved to be a predictor of the observed richness, diversity and evenness of the cork oak stands.

Regarding pedological traits, we found large plasticity in Q. suber to substrate conditions, including the $\mathrm{pH}$ of the rhizosphere and the geological substrate. Average soil $\mathrm{pH}$ ranged between 6 and 7 in all study sites, which is consistent with values reported in the literature (Cucchi 1963). Our results also match the preference of $Q$. suber for soils with acid or sub-acid reaction, together with a tendency to avoid limestone soils (Duque-Lazo et al. 2018). However, the total calcium content in soils and its active portion should be distinguished. The cork oak, like the sweet chestnut (Castanea sativa Mill.) and the common bracken (Pteridium aquilinum (L.) Kuhn), may tolerate a rather high content of soluble limestone (Ozenda 1982). Interestingly, recent research has found natural cork oak populations growing in soils with an active lime content below $26 \%$ and soil $\mathrm{pH}$ close to 8 (Duque-Lazo et al. 2018). Q. suber rarely develops in podzols and regosols (Simões et al. 2016), whereas more frequently is found in cambisols (Aponte et al. 2013) with a moderately thick humic horizon and subacidic soil $\mathrm{pH}$. In the pedon profiles, the presence of nitrates proves that rhizosphere activity is mostly concentrated in the first 30 centimeters of soil depth. Subsequently, the scarcity of phosphorus, the excess of calcium and sodium, counterbalanced by similar concentrations of chlorides and sulphates, characterize all the pedon profiles. The average depth of the described pedons falls within the range reported in the literature (Dettori et al. 2001). Soluble ions, particularly sodium, do not disturb the cork oak, though excess calcium most likely does (Maghnia et al. 2017). In fact, at each depth, molar ratios $\mathrm{Na} / \mathrm{Ca}$ were always higher than 1 , while $\mathrm{Mg} / \mathrm{Ca}$ ratio was at maximum 0.6 , and $\mathrm{Na} / \mathrm{K}$ ratio 
was permanently higher than 20 . It is plausible that the high Ca content, deriving from parent material, may represent a major obstacle for the colonization of forest species typical of more mature stages, thus favouring the cork oak. Furthermore, cork oak may produce changes in soil nutrient content, particularly $\mathrm{N}$ and $\mathrm{Ca}$, affecting the composition of soil microbial community (Aponte et al. 2013). This would explain the good establishment and natural regeneration even on dolomitic limestones found on Mt. Gibilmesi, Mt. Petroso and Costa Sant'Anna near Mt. Cuccio, where Q. suber was planted during the second half of the twentieth century (Cutino et al. 2018). In agreement with its general ecological behaviour, on the Mountains of Palermo Q. suber seems to play a dominant role only in macro-area $B$, characterized by acidic soils and rocky outcrops. This finding suggests some peculiar adaptation to local conditions in the other macro-areas; for instance, the ability of cork oak seedlings to withstand iron deficiency has been proved (Gogorcena et al. 2001).

As far as soil erosion is concerned, the calcareous substrates colonized by Q. suber are in tight contact with (and once were underneath) the flysch outcrops, mainly quartz sandstones and argillites ( $\mathrm{Ca}$ talano et al. 1978). Due to the heavy impact of human activities since prehistoric and protohistoric times, the upper lithological layers (flysch) may have been eroded, remaining obliterated or reduced to small pockets in cracks of the underlying carbonate layers. In any case, if the general conditions for establishment of the species exist, the plasticity of the cork oak (Maghnia et al. 2017) may induce deep transformations on soil characteristics over time.

The issue of how to interpret the dynamic role played by cork oak in the vegetation of the thermo- and meso-Mediterranean is still under debate (Brullo et al. 2009). In the progressive succession of the Mediterranean vegetation, many authors (Di Benedetto et al. 1985) are in agreement when considering the cork oak stands as an edaphic and stable climax, linked to loose soils with an acid reaction, and assigning them to the Quercion ilicis alliance. Conversely, other authors framed them within the Erico-Quercion ilicis, which includes all the evergreen western Mediterranean forests dominated by evergreen oaks (Brullo et al. 2009, Guarino \& Pasta 2017). Within its natural distribution range, including Sicily, the cork oak seems chiefly to characterize sub-optimal facies compared to local climax forests, whereas only rarely playing a primary role (Selvi \& Viciani 1999). However, due to the total lack of examples of undisturbed forest vegetation within the whole range of the Mountains of Palermo (Pasta 1993), forecasting the possible dynamic evolution of cork oak stands is rather complex, making impossible to assess which were the most mature "final" forests adapted to local edapho-climatic con- straints. Mixed oak woods must have been the rule before man favoured holm oak, cork oak and manna-ashes (Fraxinus ornus) to the detriment of deciduous oaks (e.g., Quercus pubescens and Quercus cerris) by coppicing native woodlands. Conversely, it is well known that regressive processes affect these ecosystems when the disturbance is more intense and/or more frequent than the cork oak's regeneration and recovery ability. Due to the combined effects of overgrazing and wildfires, cork oak stands are initially replaced by speciespoor and structurally simplified mantle and shrubland communities, dominated by fast resprouters such as Cytisus infestus, Spartium junceum and Euphorbia characias, but also by species that are largely dispersed by wild animals, such as Pistacia lentiscus, Pistacia terebinthus, Osyris alba, Prunus spinosa, Pyrus spinosa, Rubus ulmifolius and Crataegus monogyna (La Mantia et al. 2019). If the disturbance regime is further intensified, perennial grasslands dominated by Ampelodesmos mauritanicus are the most likely fate of Q. suber stands, as has largely occurred in other areas of the western Mediterranean basin (Vilà et al. 2001). Contrarily, open and scattered cork oak stands could evolve towards more complex woodlands if grazing pressure and fire frequency decrease (Bueno et al. 2020). However, a similar scenario, consistent with the hypothesis of many authors who attribute the meaning of steady disclimax to cork oak stands, maintained by moderate disturbance regimes, especially wildfires (Barberis \& Mariotti 1979), should be supported by further qualitative and quantitative investigations.

As far as our study sites are concerned, they have been particularly prone to intense and frequent human pressure (mostly wildfires and overgrazing) for millennia. Natural woodlands, including cork oak stands, have been exploited or cleared since proto-historical times. The land patches between these forests have been historically devoted to other agro-pastoral land uses (leaving no tree species), because agroforestry systems like dehesa do not belong to local Sicilian farming tradition. Accordingly, the surveyed cork oak stands can be interpreted as the last remnant nuclei of once more widespread forest patches. Such worrying conditions of the territory under investigation are further exacerbated by the lack of effective protection regime as none of the surveyed forest stands falls within protected sites, and by the still high impact of wildfires. Hence, we deem that these cork oak stands would deserve full protection as their survival in a medium to long-term perspective is far from guaranteed.

\section{Conclusions}

Compared to other evergreen oaks, cork oak has a more restricted ecological niche, particularly concerning soil humidity. Moreover, a decline of Q. suber is foreseen, es- pecially at the edge of its natural range, due to overgrazing, high fire frequency, soil pathogens and land-use changes. We studied several cork oak populations on soils deriving from calcareous bedrock, which are generally less suited to the species. Based on our results, we hypothesized that the local presence of Q. suber could depend on high fire frequency, the peculiar biogeochemistry of local soils (e.g., high Ca content), and erosion, which caused the re-emergence of calcareous substrates. The evolution of these stands is hardly predictable as strictly linked to disturbance frequency and intensity (mostly wildfires). Monitoring activities and protection measures are highly necessary to contrast the likely future shrinkage of these populations, which are threatened by extremely high fire frequency and overgrazing, as well as the likely negative effects of climate change on regeneration ability and survival rate.

\section{Acknowledgements}

The individual contributions of authors are the following: RS, TLM and SP conceived the study and established methodology; EB, RS, TLM, RSB, GS, GMP, AG and SP collected and analyzed data; GMP, AG and SP carried out field surveys; RSB performed the statistical analysis; EB, RS, TLM, RSB, GMP and SP wrote the manuscript.

This work was financially supported by the PRIN2010-11 "CARBOTREES" (Climate change mitigation strategies in tree crops and forestry in Italy - national coordinator: R. Valentini), funded by the Italian Ministry of Education, University and Research, and by Tommaso La Mantia's funding Pj autf 008567.

We thank the reviewers for significantly improving the quality of the manuscript and for providing us with useful suggestions. Thanks are due to Broni Hornsby for the revision of the English.

\section{References}

Anonymous (1996). Linee guida del piano territoriale paesistico regionale [Guidelines of the regional landscape territorial plan]. Assessorato dei Beni Culturali, Ambientali e della Pubblica Instruzione - Regione Siciliana, Palermo, Italy, pp. 615. [in Italian]

Anselin L, Syabri I, Kho Y (2006). GeoDa: an introduction to spatial data analysis. Geographical Analysis 38: 5-22. - doi: 10.1111/j.0016-7363.20 05.00671.x

Aponte C, García LV, Marañón T (2013). Tree species effects on nutrient cycling and soil biota: a feedback mechanism favouring species coexistence. Forest Ecology and Management 309: 36-46. - doi: 10.1016/j.foreco.2013.05.035

Aronson J, Pereira JS, Pausas JG (2009). Cork oak woodlands on the edge: ecology, adaptive management, and restoration. Island Press, Washington, DC, USA, pp. 315.

Badalamenti E, Pasta S, La Mantia T, La Mela Veca DS (2018). Criteria to identify old-growth forests in the Mediterranean: a case study from Sicily based on literature review and some man- 
agement proposals. Feddes Repertorium 129: 25-37. - doi: 10.1002/fedr.201700009

Barberis A, Dettori S, Filigheddu MR (2003). Management problems in Mediterranean cork oak forests: post-fire recovery. Journal of Arid Environments 54: 565-569. - doi: 10.1006/jare.20 02.1079

Barberis G, Mariotti M (1979). Notizie geobotaniche su Quercus suber L. in Liguria [Geobotanical news about Quercus suber L. in Liguria] Archivio Botanico e Biogeografico Italiano 55: 62-82. [in Italian]

Bazan G, Marino P, Guarino R, Domina G, Schic chi R (2015). Bioclimatology and vegetation se ries in Sicily: a geostatistical approach. Annales Botanici Fennici 52: 1-18. - doi: 10.5735/085.052. 0202

Blasi C, Carranza ML, Frondoni R, Rosati L (2000). Ecosystem classification and mapping: a proposal for Italian landscapes. Applied Vegetation Science 3: 233-242. - doi: 10.2307/1479002 Blasi C, Filesi L, Fratini S, Stanisci A (1997). Le cenosi con sughera nel paesaggio tirrenico laziale (Italia centrale) [The cenoses with the cork oak in the Tyrrhenian landscape of Lazio (central Italy)]. Ecologia Mediterranea 23: 21-32. [in Italian] - doi: $10.3406 /$ ecmed.1997.1834

Braun-Blanquet J (1932). Plant sociology. MC Graw-Hill, New York,London, pp. 439.

Bresc H (1983). Disfari et perdiri li fructi et li aglandi: economie e risorse boschive nella Sicilia medievale (XIII-XV secolo) [Undo and lose the fruits and acorns: economies and wood resources in medieval Sicily $\left(13^{\text {th }}-15^{\text {th }}\right.$ century)]. Quaderni Storici, Ancona 54: 941-969. [in Italian]

Brullo S, Gianguzzi L, La Mantia A, Siracusa G (2009). La classe Quercetea ilicis in Sicilia [The Quercetea ilicis class in Sicily]. Bollettino Accademia Gioenia Scienze Naturali Catania 41: 1124. [in Italian]

Bueno RS, García D, Galetti M, La Mantia T (2020). Past cover modulates the intense and spatially structured natural regeneration of woody vegetation in a pastureland. Plant Ecology 221: 205-218. - doi: 10.1007/s11258-020-0100 6-3

Camerano P, Cullotta S, Varese P (2011). Strumenti conoscitivi per la gestione delle risorse forestali della Sicilia. Tipi forestali [Knowledge tools for the management of forest resources in Sicily. Forest types]. Assessorato Territorio e Ambiente Regione Siciliana, Litograf Ed. s.r.l., Città di Castello, Perugia, Italy, pp. 192. [in Italian]

Catalano R, Abate B, Renda P (1978). Carta geologica dei Monti di Palermo (scala 1:50.000). [Geological map of of the Mounts of Palermo] Istituto di Geologia e Geodesia dell'Università di Palermo, Palermo, Italy. [in Italian]

Corona P, Dettori S, Filigheddu MR, Maetzke F, Scotti R (2005). Site quality evaluation by classification tree: an application to cork quality in Sardinia. European Journal of Forest Research 124: 37-46. - doi: 10.1007/s10342-004-0047-1

Costa A, Madeira M, Oliveira AC (2008). The relationship between cork oak growth patterns and soil, slope and drainage in a cork oak woodland in Southern Portugal. Forest Ecology and Management 255: 1525-1535. - doi: 10.1016/j. forec0.2007.11.008
Cucchi C (1963). Su una nuova stazione di Quercus suber L. in territorio di Deiva (La Spezia) [On a new station of Quercus suber $L$. in the territory of Deiva (La Spezia)]. Giornale Botanico Italiano 70: 99-109. [in Italian]

Cutino I, Pasta S, Maggiore CV, Badalamenti E, La Mantia T (2018). The role of dominant tree cover and silvicultural practices on the post-fire recovery of Mediterranean afforestations. Annals of Silvicultural Research 42: 20-31. - doi: 10.12899/asr-1482

Dettori S, Filigheddu MR, Deplano G, Molgora JE, Ruiu M, Sedda L (2018). Employing a spatiotemporal contingency table for the analysis of cork oak cover change in the Sa Serra region of Sardinia. Scientific Reports 8: 16946. - doi: 10.1038/s41598-018-35319-1

Dettori S, Filigheddu MR, Gutierrez M (2001). La coltivazione della Quercia da sughero [The cultivation of the cork oak]. Dipartimento di Economia e Sistemi Arborei Università degli Studi di Sassari, Tipografia TAS, Sassari, Italy, pp. 140. [in Italian]

Di Benedetto G, Maugeri G, Poli Marchese E (1985). Principali tappe del dinamismo della vegetazione nelle sugherete della Sicilia SudOrientale [Main stages of the dynamism of vegetation in the cork oak forests of south-eastern Sicily]. Notiziario della Società Italiana di Fitosociologia 19: 5-12. [in Italian]

Dias FS, Miller DL, Marques TA, Marcelino J, Caldeira MC, Orestes Cerdeira J, Bugalho MN (2016). Conservation zones promote oak regeneration and shrub diversity in certified Mediterranean oak woodlands. Biological Conservation 195: 226-234. - doi: 10.1016/j.biocon.2016.01.009 Dormann FC, McPherson JM, Araújo MB, Bivand R, Bolliger J, Carl G, Davies RG, Hirzel A, Jetz W, Kissling WD, Kühn I, Ohlemüller R, Peres-Neto PR, Reineking B, Schröder B, Schurr FM, Wilson $R$ (2007). Methods to account for spatial autocorrelation in the analysis of species distributional data: a review. Ecography 30: 609-628. doi: 10.1111/j.2007.0906-7590.05171.x

Duque-Lazo J, Navarro-Cerrillo RM, Ruíz-Gómez FJ (2018). Assessment of the future stability of cork oak (Quercus suber L.) afforestation under climate change scenarios in Southwest Spain. Forest Ecology and Management 409: 444-456. - doi: 10.1016/j.foreco.2017.11.042

Duro A, Piccione V, Scalia C, Zampino D (1993). Precipitazioni e temperature medie mensili in Sicilia relative al sessantennio 1926-1985 [Average monthly rainfall and temperatures in Sicily for the sixty years 1926-1985] In: Proceedings of the " 5 "Workshop del Progetto Strategico CNR Clima Ambiente e Territorio del Mezzogiorno" (Piccione V, Antonelli C eds). CNR editore, Amalfi, Italy, pp. 17-103. [in Italian]

EUFORGEN (2019). Distribution map of cork oak (Quercus suber). European Forest Genetic Resources Programme - EUFORGEN, Rome, Italy, web site. [online] URL: http://www.euforgen. org/species/quercus-suber/

Fierotti G (1988). Carta dei suoli della Sicilia (scala 1:250.000) [Soil map of Sicily]. Regione Siciliana, Assessorato Territorio e Ambiente, Palermo, Italy. [in Italian]

Gogorcena Y, Molias N, Larbi A, Abadía J, Abadía A (2001). Characterization of the responses of cork oak (Quercus suber) to iron deficiency.
Tree Physiology 21: 1335-1340. - doi: 10.1093/tree phys/21.18.1335

Guarino R, Cusimano D, llardi V, Pasta S (2017). Syntaxonomic list of the vegetation units. In: "Botanical Excursions in Central and Western Sicily. Field Guide for the $60^{\text {th }}$ IAVS Symposium" (Guarino R, Pasta S eds). UNIPAPRESS, Palermo, Italy, pp. 281-370.

Guarino R, Pasta S (2017). Botanical excursions in Central and Western Sicily. Field Guide for the $60^{\text {th }}$ IAVS Symposium. UNIPAPRESS, Palermo, pp. 604.

Gussone G (1842). Florae Siculae Synopsis exhibens plantas vasculares in Sicilia insulisque adjacentibus hucusque detectas secundum systema Linnaeanum dispositas [Synopsis of flora of Sicily including vascular plants in Sicily and surrounding island, classified according to Linnaean taxonomy]. Typography Tramater, Naples, Italy, pp. 582. [in Italian]

Houston Durrant T, De Rigo D, Caudullo G (2016). Quercus suber in Europe: distribution, habitat, usage and threats. In: "European Atlas of Forest Tree Species” (San-Miguel-Ayanz J, de Rigo D, Caudullo G, Houston Durrant T, Mauri A, Luxembourg eds). Publication Office of the European Union, Luxembourg, pp. 164-165. [online] URL: https://forest.jrc.ec.europa.eu/en/europea n-atlas/

INFC (2007). Le stime di superficie 2005 - Prima parte. Inventario nazionale delle foreste e dei serbatoi forestali di carbonio [Estimates of surfaces for 2005 - First part. National inventory of forests and carbon forest pools]. CRA - Istituto Sperimentale per l'Assestamento Forestale e per l'Alpicoltura, Trento, Italy, pp. 409. [in Italian]

IUSS Working Group (2015). World reference base for soil resources 2014, update 2015. World Soil Resources Reports no. 106, FAO, Rome, Italy, pp. 192.

La Mantia T, Rühl J, Massa B, Pipitone S, Lo Verde G, Bueno RS (2019). Vertebrate-mediated seed rain and artificial perches contribute to overcome seed dispersal limitation in a Mediterranean old field. Restoration Ecology 27: 1393-1400. - doi: 10.1111/rec.13009

Laakili A, Belkadi B, Gaboun F, Yatrib C, Makhloufi M, El Antry S, Medraoui L, Laamarti A, Filali-Maltouf A (2016). Analysis of dendrometric diversity among natural populations of cork oak (Quercus suber L.) from Morocco. Turkish Journal of Agriculture and Forestry 40: 127-135. - doi: 10.3906/tar-1407-147

Lentini F, Carbone S (2014). Geologia della Sicilia, con i contributi di Branca S (vulcanico) e Messina A (basamenti cristallini) [Geology of Sicily, with the contributions of Branca $S$ (volcanic) and Messina A (crystalline bases)]. In: "Memorie Descrittive della Carta Geologica d'Italia”, vol. 95. ISPRA, Italy, pp. 7-414. [in Italian] Lojacono-Pojero M (1888). Flora Sicula o descrizione delle piante spontanee o indigenate in $\mathrm{Si}$ cilia [Sicilian flora Sicula or description of spontaneous or naturalized plants in Sicily]. A Forni Editore, Bologna, Italy, pp. 1-722. [in Italian] Maghnia FZ, Abbas Y, Mahé F, Kerdouh B, Tournier E, Ouadji $M$, Tisseyre $P$, Prin $Y$, El Ghachtouli N, Bakkali Yakhlef SE, Duponnois R, Sanguin $H$ (2017). Habitat- and soil-related drivers of the root-associated fungal community of 
Quercus suber in the Northern Moroccan forest. PLoS One 12: e0187758. - doi: 10.1371/jour nal.pone. 0187758

Marcenò C, Trapani S (1978). L'Isoëtetum duriaei (Isoëtion) nella Piana dei Greci (Sicilia occidentale) [Isoëtetum duriaei (Isoëtion) in the Plain of Greeks (western Sicily)]. Atti dell'Accademia di Scienze, Lettere e Arti, Palermo 1: 395-399. [in Italian]

Matías L, Abdelaziz M, Godoy O, Gómez-Aparicio $L$ (2019). Disentangling the climatic and biotic factors driving changes in the dynamics of Quercus suber populations across the species latitudinal range. Diversity and Distributions 25: 524-535. - doi: 10.1111/ddi.12873

Minissale P, Musumarra G, Sciandrello S (2006). La vegetazione di Poggio Racineci (Caltagirone - Sicilia centro-meridionale) un biotopo da proporre come sito di Interesse Comunitario [The vegetation of Poggio Racineci (Caltagirone central-southern Sicily) a biotope to be proposed as a site of Community Importance]. Bollettino dell'Accademia Gioenia di Scienze Naturali, Catania 39: 21-41. [in Italian]

Ozenda $P$ (1982). Les végétaux dans la biosphère [The plants in the biosphere]. Revue de Géographie Alpine 70: 310-311. [in French]

Parlatore F (1848). Flora Italiana ossia descrizione delle piante che crescono spontanee o vegetano come tali in Italia e nelle isole ad essa adiacenti disposte secondo il metodo naturale [Italian Flora or description of plants that spontaneously grow in Italy and in the islands adjacent to it arranged according to the natural method]. Le Monnier, Firenze, Italy, vol. 1, pp. 568. [in Italian]

Pasta S (1993). Considerazioni teoriche sulle prospettive di ricerca aperte dalla geobotanica ed esempi di applicazioni di questa disciplina al caso specifico dello studio della flora e della vegetazione di un settore dei Monti di Palermo [Theoretical considerations on the research prospects opened by geobotany and examples of applications of this discipline to the specific case of the study of the flora and vegetation of a sector of the Palermo Mounts]. Degree Thesis in Natural Sciences, University of Palermo, Italy, pp. 330. [in Italian]

Pasta S, Troìa A (1994). Contributo alla conoscenza della Flora dei Monti di Palermo (Sicilia nord-occidentale) [Contribution to the knowledge of the Flora of the Mounts of Palermo (north-western Sicily)]. II Naturalista Siciliano 18: 15-27. [in Italian]

Pausas JG (1997). Resprouting of Quercus suber in NE Spain after fire. Journal of Vegetation Science 8: 703-706. - doi: 10.2307/3237375
Petroselli A, Vessella F, Cavagnuolo L, Piovesan G, Schirone B (2013). Ecological behavior of Quercus suber and Quercus ilex inferred by topographic wetness index (TWI). Trees 27: 12011215. - doi: $10.1007 /$ s00468-013-0869-x

Pignatti S, Guarino R, La Rosa M (2017). Flora d'Italia [Flora of Italy] (2 ${ }^{\text {nd }}$ edn). Edagricole, Bologna, voll. 4, pp. 583. [in Italian]

Pignatti S, Mengarda F (1962). Un nuovo procedimento per l'elaborazione delle tabelle fitosociologiche [A new procedure for the processing of the phytosociological tables]. Rendiconti dell'Accademia Nazionale dei Lincei 32: 215-221. [in Italian]

Pollastrini M, Chiavetta U, Cutini A, Casula A, Maltoni S, Dettori S, Corona P (2018). Indicators for the assessment and certification of cork oak management sustainability in Italy. iForest Biogeosciences and Forestry 11: 668-674. - doi: 10.3832/ifor2587-011

R Core Team (2019). R: a language and environment for statistical computing, version 3.6.1. $\mathrm{R}$ Foundation for Statistical Computing, Vienna, Austria. [online] URL: http://www.r-project.org Rivas-Martínez S (1996). Classificación bioclimatica de la Tierra [Bioclimatic classification of the Earth]. Folia Botanica Matritensis 16: 1-32. [in Spanish]

Schoeneberger PJ, Wysocki DA, Benham EC, Broderson WD (2002). Field book for describing and sampling soils, version 2.0. National Soil Survey Center, USDA, Lincoln, NE, USA, pp. 300. [online] URL: http://www.nrcs.usda.gov/ wps/portal/nrcs/detail/soils/research/guide/?cid $=$ nrcs142p2_054184

Selvi F, Viciani D (1999). Contributo alla conoscenza vegetazionale delle sugherete della Toscana [Contribution to the vegetational knowledge of the cork oak stands of Tuscany]. Parlatorea 3: 45-63. [in Italian]

Serrasolses I, Pérez-Devesa M, Vilagrosa A, Pausas JG, Sauras T, Cortina J, Vallejo VR (2009). Soil properties constraining cork oak distribution. In: "Cork oak woodlands on the edge: ecology, adaptive management, and restoration (Aronson J, Pereira JS, Pausas JG eds). Island Press, Washington, DC, USA, pp. 89-99. [online] URL: http://digital.csic.es/bitstream/102 61/38769/1/CorkoakCap.8(JGPausas).pdf

Shannon CE (1948). A mathematical theory of communication. The Bell System Technical Journal 27: 379-423. - doi: 10.1002/j.1538-7305.19 48.tbo1338.x

Simões MP, Belo AF, Fernandes M, Madeira M (2016). Regeneration patterns of Quercus suber according to montado management systems. Agroforestry Systems 90: 107-115. - doi: 10.1007/ s10457-015-9818-6

Sirca C, Filigheddu MR, Zucca GM, Cillara M, Bacciu A, Bosu S, Dettori S (2015). Long-term researches on post fire recovery techniques of cork oak stands. In: Proceedings of the 2 nd International Congress of Silviculture "Designing the future of the forestry sector". Florence (Italy) 26-29 Nov 2014. AISF, Florence, Italy, pp. 491-496.

Tüxen R, Ellenberg H (1937). Der systematische und der ökologische Gruppenwert. Ein Beitrag zur Begriffsbildung und Methodik der Pflanzensoziologie. Mitteilungen der Floristisch-Soziologischen Arbeitsgemeinschaft [The systematic and ecological group value. A contribution to concept formation and methodology of plant sociology]. Communications from the FloristicSociological Working Group 3: 171-184. [in German]

USSAB (2005). Presentazione del "Piano Regionale per la difesa della vegetazione dagli incendi" [Presentation of the "Regional Plan for the protection of vegetation from fires"]. Ufficio Speciale Servizio Antincendio Boschivi (USSAB), Regione Siciliana, Assessorato Agricoltura e Foreste, Palermo, Italy, pp. 47. [in Italian]

Vessella F, López-Tirado J, Simeone MC, Schirone B, Hidalgo PJ (2017). A tree species range in the face of climate change: cork oak as a study case for the Mediterranean biome. European Journal of Forest Research 136: 555-569. - doi: 10.1007/s10342-017-1055-2

Vilà M, Lloret F, Ogheri E, Terradas J (2001). Positive fire-grass feedback in Mediterranean basin shrublands. Forest Ecology and Management 147: 3-114. - doi: 10.1016/S0378-1127(0o)00435-7

\section{Supplementary Material}

Tab. S1 - Land units of the surveyed areas according to the methodology developed by Blasi et al. (2000).

Tab. S2 - Results of the full phytosociological surveys.

Tab. S3 - Morphological characteristics of the pedons collected in the field.

Tab. S4 - Results of spatial autocorrelation analysis.

Tab. S5 - Results of the simplified phytosociological surveys.

Link: Badalamenti_3360@supploo1.pdf 